\title{
Ogniskowa dysplazja korowa - aktualny stan wiedzy z uwzględnieniem populacji pediatrycznej
}

\section{Focal cortical dysplasia - current knowledge including pediatric population}

\author{
Agnieszka Cebula', Ilona Kopyta² \\ 1. Oddział Pediatrii i Neurologii Wieku Rozwojowego, Górnośląskie Centrum Zdrowia Dziecka, 40-752 Katowice, ul. Medyków 16 \\ 2. Katedra i Klinika Neurologii Dziecięcej, Śląski Uniwersytet Medyczny w Katowicach, Wydział Lekarski w Katowicach, \\ 40-752 Katowice, ul. Medyków 16 \\ DOI:10.20966/chn.2017.53.410
}

\section{STRESZCZENIE}

Ogniskowa dysplazja korowa (FCD), będąca wynikiem zaburzonej migracji neuronalnej, pozostaje najczęstszą przyczyną neurochirurgicznego leczenia pacjentów z padaczką lekooporną, stanowiąc zarazem istotny problem zarówno w populacji dorostej, jak i pediatrycznej. Pomimo obszerności poświęconej jej literatury naukowej, choroba ta, manifestująca się najczęściej pod postacią padaczki, pozostaje wyzwaniem zarówno w procesie diagnostyki, jak i w zakresie możliwości jej leczenia. Jej patogeneza pozostaje niejasna, a aktualnie stosowana klasyfikacja budzi pewne wątpliwości, zwłaszcza wobec braku odzwierciedlenia podziału w manifestacji klinicznej, rokowaniu i wynikach badań diagnostycznych poszczególnych typów. Ze względu na ograniczenia dostępnych i rutynowo stosowanych metod diagnostycznych, występowanie FCD, również w populacji bezobjawowej, wydaje się niedoszacowane. Nie ulega jednak wątpliwości, że jej udział w grupie pacjentów z padaczką lekooporną hospitalizowanych w oddziałach neurologii dziecięcej jest znaczny i dalsze próby zrozumienia tej jednostki chorobowej, a także opracowania skutecznych możliwości jej terapii są konieczne. Niniejszy artykuł jest próbą skróconego przedstawienia aktualnej wiedzy dotyczącej tej jednostki - jej obrazu klinicznego, podziału, patogenezy, diagnostyki, leczenia oraz rokowania. Słowa kluczowe: malformacje rozwoju kory nerwowej, ogniskowa dysplazja korowa, padaczka, pediatria

\section{ABSTRACT}

Focal cortical dysplasia (FCD), which is a result of a disturbed neuronal migration, remains the most common reason for neurosurgeries among patients with drug resistant epilepsy and proves to be a significant challenge in both adult and pediatric population. In spite of being one of the most important researched subjects, making diagnosis of FCD and treating its symptoms usually manifested as epilepsy, is still difficult. Furthermore, FCDs pathogenesis remains unclear and there are some doubts about its current classification, since there are very few differences between types with regard to symptoms, prognosis and diagnostic tests results. As a consequence of limitations of currently used and available diagnostic methods, FCDs prevalence in both healthy and symptomatic population appears to be underrated. Nevertheless, it is unquestionable that FCD is a common cause for hospitalization in children's neurological wards and further research is needed. The goal of this article is to present current knowledge about this medical condition - its clinical presentation, classification, pathogenesis, process of making diagnosis, treatment and prognosis.

Keywords: malformations of cortical development, focal cortical dysplasia, epilepsy, pediatrics
Ogniskowa dysplazja korowa (FCD - focal cortical dysplasia), będąca wynikiem nieprawidłowej migracji neuronalnej, stanowi najczęstszą przyczynę interwencji neurochirurgicznych w populacji dzieci chorujących na padaczkę [1]. Jednostka opisana została przez Taylora wraz ze współautorami w 1971 roku [2]. Z uwagi na znaczące trudności w procesie diagnostycznym nie jest możliwe określenie precyzyjnej częstości występowania tego schorzenia w populacji. Przyjmuje się, że pośród wszystkich pacjentów z padaczką FCD stanowi ok $10 \%$ przypadków. Odsetek ten wzrasta wśród chorych na padaczkę lekooporną poddaną leczeniu neurochirurgicznemu i wynosi $50 \%$ [3]. Rozpoznanie to stawiane jest zazwyczaj już w okresie dzieciństwa. W grupie pacjentów leczonych neurochirurgicznie w $75-80 \%$ przypadków FCD rozpoznano w pierw- szych 3 latach życia, a tylko w 10\% powyżej 21 roku życia. [3, 4]. Zmiany typowe dla FCD mogą zająć dowolną lokalizację w obrębie kory mózgowej, jednak najczęściej powstają w płacie skroniowym i stanowią ok. $50 \%$ przypadków [5-7]. Drugą z najczęstszych lokalizacji występowania są płaty czołowe $-20 \%$ [7]. W około $20-30 \%$ przypadków występują mnogie ogniska w różnych płatach, co znacząco utrudnia zarówno proces diagnostyczny, jak i terapię $[1,7]$.

\section{KLASYFIKACJA FCD}

W 2011 roku Międzynarodowa Liga Przeciwpadaczkowa (International League Against Epilepsy - ILAE) opracowała nową, bazującą na obrazie histologicznym, trzypoziomową klasyfikację FCD (tab.I). Zastąpiła ona 
wcześniej istniejące, - m.in. klasyfikację Palminiego. Najistotniejszą zmianę stanowi wyodrębnienie typu III-FCD związaną z innymi schorzeniami podstawowymi.

Typ I klasyfikacji obejmuje przede wszystkim zaburzenia w architekturze warstw kory mózgowej. Typ II odpowiada zmianom zarówno w architekturze warstw, jak i w obrębie neuronów. Do typu III należą przypadki FCD występujące u pacjentów $\mathrm{z}$ innym rozpoznaniem podstawowym, o zmianach zlokalizowanych zazwyczaj w bezpośrednim sąsiedztwie bądź tym samym płacie. W obrębie poszczególnych typów rozróżnianie są podklasy. W przypadku stwierdzenia FCD i podejrzewania istnienia innej patologii układu nerwowego niemożliwej do potwierdzenia, dopuszczalne jest rozpoznanie FCD typ III NOS (not otherwise specified) [5].

Pośród pacjentów z potwierdzonym rozpoznaniem FCD, typ II pozostaje najczęstszą postacią i dotyczy 29-52,6\% przypadków [7-9]. Odsetek ten jest wyższy w populacji pediatrycznej [8].

Powyższa klasyfikacja koncentruje się na zagadnieniach histopatologicznych, a różnice w obrazie klinicznym pomiędzy poszczególnymi typami nie zawsze są wyraźne. Według części źródeł typ II FCD charakteryzuje się wcześniejszym wystąpieniem napadów padaczkowych i większą ich częstotliwością [10]. Według innych napady są częstsze w typie I [6]. Podczas gdy FCD II częściej zajmuje lokalizacje pozaskroniową, typ I wielokrotnie sąsiaduje z korowymi ośrodkami mowy oraz wiąże się z gorszym rokowaniem w przypadku leczenia neurochirurgicznego [11-13]. Ponadto typ I częściej niż II pozostaje niewykrywalny $\mathrm{w}$ badaniu rezonansu magnetycznego (MR) $[4,7$,
11]. FCD II ma lepszą wykrywalność również w innych badaniach obrazowych - tomografii emisyjnej pojedynczych fotonów (SPECT) i pozytonowej tomografii emisyjnej (PET) [14]. Co ciekawe, udowodniono, że izolowana FCD I ma gorsze rokowanie niż FCD III ze składową FCD I (wyłączając z analizy podtyp FCD IIId) [6].

Pewną kontrowersję budzi wydzielenie w klasyfikacji typu IIIa i jego rozdzielenie od typu I. Wynika to z wątpliwości co do możliwości współwystępowania stwardnienia hipokampa (ang. hipocampal sclerosis; HS) oraz FCD I w wyniku niezależnej bądź wspólnej patogenezy, jak i postulowanej możliwości wtórnego wystąpienia jednej ze zmian w wyniku procesów zainicjowanych przez już istniejąca drugą $[5,15]$. Argumentem przemawiającym za słusznością tego podziału są różnice w obrazie klinicznym FCD I i FCD IIIA. W jednym z badań udowodniono, że w przypadku współwystępowania FCD i HS drgawki goraczkowe i występowanie aury przed napadem były istotnie częstsze, jednak nie zaobserwowano istotnych statystycznie różnic w wynikach leczenia, neuroobrazowaniu oraz przebiegu przedoperacyjnym [15]. Wyniki te pozostają w sprzeczności z doniesieniem Tassi i współautorów, którzy wykazali, że izolowana FCD I cechuje się wyższą niż w przypadku FCD IIIa częstością napadów oraz gorszym wynikiem leczenia [6]. Istnieją jednak sugestie, że różnice te nie wynikają z obecności HS, a z częstszego lokalizowania się pojedynczych zmian w płatach skroniowych w grupie FCD IIIa, w porównaniu do FCD I. Dodatkowo w grupie FCD I częściej obserwowane są mnogie ogniska. Aktualnie niemożliwa więc wydaje się być ocena

Tabela I. Klasyfikacja ogniskowej dysplazji korowej opracowana w 2011r przez International League Against Epilepsy (ILAE) Table I. Classification of focal cortical dysplasia (FCD) developed by the International League Against Epilepsy (ILAE) in 2011

FCD typ I - nieprawidłowa organizacja warstw kory nowe FCD type I - distortion of neocortical layers

\begin{tabular}{|c|c|c|}
\hline $\begin{array}{l}\text { FCD typ la } \\
\text { Nieprawidłowa migracja w kierunku pionowym, } \\
\text { obecne poszczególne warstwy kory mózgowej, } \\
\text { mikrokolumny (więcej niż } 8 \text { neuronów w kierunku } \\
\text { pionowym w przypadku prostopadłego do } \\
\text { powierzchni kory mózgowej wycinka) }\end{array}$ & $\begin{array}{l}\text { FCD typ Ib } \\
\text { Nieprawidłowa migracja w kierunku stycznym } \\
\text { - zaburzona budowa 6-warstwowa kory. }\end{array}$ & $\begin{array}{l}\text { FCD typ Ic } \\
\text { Nieprawidłowa migracja } \\
\text { neuronów zarówno } \\
\text { w kierunku pionowym } \\
\text { jak i stycznym. }\end{array}$ \\
\hline
\end{tabular}

FCD typ II - nieprawidłowa architektura warstw oraz nieprawidłowości cytologiczne FCD type II - architectural distortion of layers and cytological abnormalities

\begin{tabular}{l|l}
\hline FCD typ lla & FCD typ II b
\end{tabular}

Nieobecna budowa warstwowa kory, neurony dysmorficzne, wyznaczenie granicy między korą a istotą białą często niemożliwe
Nieobecna budowa warstwowa, dysmorficzne neurony oraz neurony balonowate (o dużych, "rozdętych" perykarionach, ze szklistą eozynofilową cytoplazmą, bez ciałek Nissla), często towarzyszące zaburzenia mielinizacji sąsiadującej istoty białej.

FCD typ III - FCD towarzysząca innej chorobie neurologicznej FCD type III - FCD type III accompanied by another neurological disease

\begin{tabular}{|c|c|c|c|}
\hline $\begin{array}{l}\text { FCD typ Illa } \\
\text { FCD towarzysząca } \\
\text { stwardnieniu hipokampa }\end{array}$ & $\begin{array}{l}\text { FCD typ Illb } \\
\text { FCD towarzysząca } \\
\text { guzom (np. } \\
\text { ganglioglioma, DNET) }\end{array}$ & $\begin{array}{l}\text { FCD typ Illc } \\
\text { FCD towarzysząca } \\
\text { malformacjom } \\
\text { naczyniowym }\end{array}$ & $\begin{array}{l}\text { FCD typ IIId } \\
\text { FCD towarzysząca innym patologiom } \\
\text { układu nerwowego, nabytym w okresie } \\
\text { wczesnego dzieciństwa. (m.in. niedotlenieniu } \\
\text { krwawieniom, infekcjom etc.) }\end{array}$ \\
\hline
\end{tabular}


czy różnice opisywane między tymi dwoma typami w istocie wynikają z współistnienia HS [15].

Należy również pamiętać, że możliwe jest występowania różnych typów FCD, w różnych lokalizacjach OUN, u jednego pacjenta [16].

\section{OBRAZ KLINICZNY}

Mimo iż ogniskową dysplazję korową zwyczajowo utożsamia się z padaczką i taka też jest jej najczęściej spotykana prezentacja kliniczna, możliwy jest jej beznapadowy przebieg. Piśmiennictwo zawierające opisy bezobjawowych przypadków jest ograniczone. W jednej retrospektywnej analizie badań MR w populacji pediatrycznej $29 \%$ pacjentów z FCD nie prezentowało napadów. Praca ta objęła 97 pacjentów poniżej 18 roku życia, wybranych na podstawie retrospektywnej analizy danych pracowni MR pod kątem słów kluczy oraz ponownej weryfikacji obrazu przez radiologa $\mathrm{z}$ doświadczeniem $\mathrm{w}$ neuroobrazowaniu. Istotnym ograniczeniem wiarygodności uzyskanych wyników jest bardzo mała liczba przypadków FCD $(n=22)$ zweryfikowanych w badaniu histopatologicznym. Pozostałe rozpoznania zostały postawione na podstawie konstelacji zmian w wykonanym badaniu MR. Co równie istotne, badanie to nie dotyczyło generalnej populacji pediatrycznej, a jedynie pacjentów, u których wystąpiła konieczność wykonania MR [17].

Charakter epizodów napadowych u pacjentów z FCD zależy od lokalizacji i wielkości zmian. Najczęściej są to napady padaczkowe ogniskowe, jednak opisano też napady zgięciowe, napady ogniskowe wtórnie uogólnione, a także stany padaczkowe [8]. Napady padaczkowe często poprzedza aura (58-90\% pacjentów). Najczęściej jest to aura epigastryczyna, o charakterze różnorodnych dolegliwości w nadbrzuszu (28-51\% pacjentów w zależności od typu) [15]. U 10-35\% pacjentów z FCD, szczególnie w typie III, występują drgawki gorączkowe [15]. W większości przypadków napady zaczynają się w dzieciństwie - średnia wieku wystąpienia pierwszego napadu, w zależności od źródeł, wynosiła 2,6 -10,4 lat [4, 7, 10, 18]. Przyjmuje się, że u $60 \%$ pacjentów pierwszy napad wystąpi przed piątym rokiem życia, a jedynie u $10 \%$ chorych istnienie zmian o typie FCD nie będzie manifestowało się napadami padaczkowymi do okresu dorosłości [8, 17]. 46\% przypadków padaczki z FCD ma przebieg lekooporny. Dla porównania, w przypadku generalnej populacji pacjentów chorujących na padaczkę odsetek padaczek lekoopornych wynosi niemal dwa razy mniej, 25-30\% [17]. Około 70\% chorych z tzw. FCD objawową, w okresie przed operacją neurochirurgiczną, ma napady codziennie [10].

W pracy Lerner J.T i wsp. na podstawie przeprowadzonych przed leczeniem operacyjnym ocen rozwoju oszacowano, że deficyty intelektualne towarzyszą 33-68\% przypadków FCD [10]. Pojedyncze doniesienia wskazują na częstsze występowanie deficytów intelektualnych w przypadku pacjentów, u których pierwszy napad miał miejsce we wczesnym dzieciństwie oraz pacjentów z grupy FCD I [8]. Warto też nadmienić, że opóźnienie psychoruchowe różnego stopnia było najczęstszą przyczyną przypadkowych rozpoznań FCD u pacjentów o beznapadowym przebiegu [17].

\section{PATOGENEZA FCD}

Przyczyna powstawania ognisk FCD w dalszym ciągu nie jest jasna. Z uwagi na niejednolity charakter tej jednostki, prawdopodobny wydaje się udział wielu czynników zarówno środowiskowych, jak i genetycznych. Dotychczasowe doniesienia analizowały udział wielu genów - m.in. CNTNAP2, PTEN, SCN1A, STXBPI, czy TSC1, TSC2 [8, 19]. Dopiero dzięki opisaniu w 2002 roku podobieństwa FCD typu II do stwardnienia guzowatego (TSC), postawiono hipotezę mówiącą o udziale zaburzeń szlaku mTOR w jej powstawaniu [20]. Mimo licznych badań dotychczasowo zaburzenia te potwierdzono jedynie w typie II FCD $[9,21,22]$.

Wśród teorii dotyczących powstawania FCD brano także pod uwagę m.in. potencjalne działanie epileptogenne onkogenu E6 wirusa HPV. W kilku pracach potwierdzono występowanie szczepów HPV związanych z onkogenem E6 wśród pacjentów z FCD IIB [23, 24]. Jednak z uwagi na umiejscowienie zmian o typie FCD w lokalizacjach innych niż charakterystyczne dla infekcji wirusowej, brak dowodów na transformację nowotworową FCD, brak dowodów na wystąpienie infekcji HPV u matek pacjentów z FCD oraz sprzeczne wyniki badań przeprowadzonych w różnych ośrodkach (w 2 nie potwierdzono obecności epitopu E6 u żadnego z pacjentów), związek infekcji wirusowej z FCD wydaje się być wątpliwy [9].

Osobnym zagadnieniem, wymagającym w dalszym ciągu wyjaśnienia, pozostaje proces samoistnego generowania zmian napadowych. Większość hipotez zakłada udział zaburzeń w obrębie receptorów glutaminianowych, NMDA oraz nieprawidłowości w funkcjonowaniu receptorów bądź ilości GABA [1, 25, 26].

\section{DIAGNOSTYKA FCD:}

Pomimo intensywnego rozwoju technik obrazowania oraz rejestracji czynności mózgu postawienie rozpoznania FCD w dalszym ciągu sprawia trudności. Najważniejszym spośród badań w toku diagnostyki oraz planowania leczenia FCD pozostaje MR. Szczególnie istotna w wykrywaniu zmian FCD jest sekwencja T2-FLAIR [11]. Cechami charakterystycznymi dla FCD w obrazie MR są: pogrubienie kory mózgowej bądź zanik korowy, zatarcie granicy między istotą szarą a białą, wzmożenie sygnału kory i strefy podkorowej w sekwencji T2-FLAIR, nieprawidłowy rozkład zakrętów i bruzd z możliwym towarzyszącym ich pogłębieniem, oraz najbardziej swoisty - objaw ,transmantle” hiperintensywne pasma w sekwencji FLAIR, promieniście odchodzące od komór i biegnące w kierunku kory, [4, 5, 10, 27, 28]. Objaw ten jest szczególnie charakterystyczny dla typu II [5, 10, 19]. Jego obecność wiąże się z częstszym występowaniem napadów padaczkowych [17].

Niestety, w wielu przypadkach (19-58\%) badań MR pacjentów z FCD nie opisano zmian charakterystycznych dla tej jednostki $[10,27,30,14]$. Część z tych przypadków to zmiany nieme w MR (FCD MR -), jednak z uwagi na niewielki rozmiar oraz częstą subtelność zmian, duży ich odsetek nie zostaje zauważony. Według części źródeł problem ten dotyczy zwłaszcza typu I [4, 7, 10, 11]. Co więcej, w typie III, FCD zostaje często przeoczone z uwagi na obecność 
innej patologii OUN [19]. Radhakrishnan i współautorzy opisali zmniejszenie liczby przeoczonych zmian z 54\% do $18 \%$, w wyniku wprowadzenia nowej klasyfikacji FCD oraz dodatkowych szkoleń w zakresie wykrywania FCD w MR [27]. W innym badaniu udowodniono, że wykonanie badań kolejno z użyciem aparatów 1,5 i 3T w tej samej grupie pacjentów wiązało się z poprawą czułości badania z $60 \%$ do $68 \%$. Aparat 3T częściej również pozwalał na uwidocznienie objawu ,transmantle" [30].

Populacja pediatryczna stanowi szczególne wyzwanie w przypadku diagnostyki MR . Opisane powyżej objawy są trudne do zidentyfikowania w niedojrzałym i nie w pełni zmielinizowanym mózgu dziecka. Opisano również przypadki „maskowania” zmian przez proces mielinizacji - zmiany dobrze widoczne w badaniu w 1 roku życia w kolejnych latach stały się niemal niewidoczne [31].

Choć elektroencefalografia (EEG) pozostaje podstawowym narzędziem oceniającym funkcję czynnościową ośrodkowego układu nerwowego, jej rola w FCD jest ograniczona. Nie istnieje zapis EEG pozwalający jednoznacznie rozpoznać FCD ani tym bardziej na różnicowanie poszczególnych typów [35]. Opisywane w tej grupie zmiany to najczęściej rytmiczne, ogniskowe wyładowania elektryczne, okresy zwolnienia zapisu tła pomiędzy napadami, pojawianie się pomiędzy napadami iglic, wieloiglic oraz fal o rytmicznym, niemal ciągłym występowaniu i częstotliwości 1-3Hz [10, 19, 35]. Podobne cechy zapisu mogą występować jednak u innych pacjentów z padaczką lekooporną. Dodatkowo, jedynie w 49-68\% przypadków zmiany w EEG korelują z lokalizacją zmiany stwierdzonej w badaniach obrazowych [10]. A wraz ze wzrastającą odległością ogniska epileptogennego od powierzchni czaszki jego wykrywalność w EEG się zmniejsza [19].

Ze względu na wspomniane ograniczenia powyższych badań diagnostycznych niezbędne w toku diagnostyki może być jej poszerzenie o dodatkowe badania, m.in. PET, SPECT, magnetoencefalografię (MEG), funkcjonalne obrazowanie metodą rezonansu magnetycznego (fMR) oraz elektrokortykografię (ECoG). Kliniczne znaczenie tych badań wzrasta zwłaszcza w przypadku równoczasowego ich zastosowania ze wspólną akwizycją danych np. MR oraz SPECT (SISCOM), MR oraz MEG (MSI), PET-MR. Duże nadzieje wiązane są także z nowymi metodami obróbki uzyskanych wyników oraz cyfrowej fuzji uzyskanych obrazów [19]. Szczególną rolę odgrywają one w przypadku niepowodzeń leczenia neurochirurgicznego, które mogą wynikać z niekompletności resekcji bądź istnienia dodatkowych ognisk niewykrytych w standardowej diagnostyce.

fMR, na podstawie zobrazowania zwiększonego przepływu krwi i utlenowania okolicy mózgu (sygnał BOLD), pozwala na określenie lokalizacji ognisk tkanki nerwowej o zwiększonej w danym momencie aktywności. Założeniem wykorzystania tej metody w FCD jest hipoteza, że są to zarazem miejsca lokalizacji epileptogennych sieci neuronów. Metoda ta jest szczególnie przydatna w przypadku jej połączenia z równoczasową elektroencefalografią [19, 33]. Jej istotną przewagą nad EEG jest możliwość uzyskania informacji o czynności struktur leżących głębiej - np. wzgórza czy hipokampu [33]. Porównując wyniki BOLD i EEG u pacjentów, u których można było przeprowadzić oba badania, wykazano ich $88 \%$ zgodność oraz możliwość uzyskania dodatkowych informacji o ogniskach epileptogennych w fMR w $64 \%$ badań [33]. Thornton i współautorzy udowodnili, że usunięcie ognisk zlokalizowanych na podstawie badań MR i EEG, ale bez uwzględnienia obszarów opisanych w fMR wiąże się z gorszym rokowaniem [34]. Istotnym ograniczeniem fMR jest konieczność wystąpienia wyładowań międzynapadowych w trakcie jego trwania. Odsetek badań niediagnostycznych $\mathrm{z}$ tego powodu, pośród pacjentów z padaczką ogniskową, wyniósł od 23 do 50\% [33].

PET z wykorzystaniem fludeoksyglukozy (FDG) jest badaniem szczególnie przydatnym w przypadku pacjentów z padaczką lekooporną, u których zarówno MR, jak i EEG nie pozwoliły na lokalizacje ogniska epileptogennego. Wykonany w okresie międzynapadowym wykazuje ogniska hipometabolizmu w miejscu ognisk FCD u 60 do 92\% wszystkich pacjentów, ale zmiany te mogą odpowiadać także propagacji aktywności napadowej zainicjowanej w innym miejscu [10, 14, 29]. W grupie pacjentów z FCD MR -, zastosowanie PET pozwala na postawienie rozpoznania w 55-95\% przypadków [10, 29, 36]. Jednak rokowanie pacjentów FCD MR-, PET + jest gorsze niż rokowanie pacjentów FCD MR + [36]. W przypadku zastosowania równoczasowej rejestracji PET-MR czułość wzrasta z 78\% w przypadku izolowanego badania PET, do $95 \%$ dla badania PET-MR [36].

Kolejne z badań tj. SPECT, pozwala na lokalizowanie ognisk FCD poprzez zobrazowanie miejsc korowej hiperperfuzji. Czułość tego badania wynosi 72-89\% i jest wyższa dla typu II [14, 37]. Mimo że MR oraz EEG stanowią złoty standard oceny kompletności resekcji ogniska, zwrócono uwagę na możliwość zastosowania w tym zakresie SPECT, podkreślając potencjalny udział tego badania w planowaniu resekcji. W analizie 106 przypadków pediatrycznych poddanych leczeniu neurochirurgicznemu porównano wyniki leczenia z oceną kompletności resekcji w różnych badaniach obrazowych (MR + EEG oraz SPECT). W przypadku oceny resekcji jako kompletnej zarówno na podstawie MR/EEG, jak i SPECT, leczenie było skuteczne u $87 \%$ pacjentów. W przypadku grupy ocenionej pozytywnie w MR/EEG a negatywnie w SPECT, odsetek ten wynosił 59\%. W przypadku pozytywnej oceny w SPECT, ale negatywnej w MR/EEG - 80\% [37]. Nie wykazano statystycznie istotnych różnic między SPECT i PET[14]. Istotnym ograniczeniem zastosowania SPECT, zwłaszcza w zakresie planowanej operacji, jest pokrywanie się obszarów hiperperfuzji z miejscami propagacji aktywności napadowej. Uwidocznione zmiany mogą więc przekraczać obszar padaczkorodny. Co więcej, podanie znacznika w trakcie trwania napadu może być trudne. A z uwagi na ponapadowo występujący spadek perfuzji ogniska epileptogennego, jego podanie w trakcie krótkiego napadu wiąże się z ryzykiem uzyskania wyniku fałszywie ujemnego [37].

Wobec trudności w precyzyjnym wskazaniu lokalizacji ognisk FCD oraz określeniu ich ewentualnego związku przestrzennego z korowymi ośrodkami mowy, nadal sze- 
rokie zastosowanie znajduje elektrokortykografia, badanie wykorzystujące elektrody wewnątrzczaszkowe [14, 34]. Badanie to, poza lokalizowaniem potencjalnych ognisk epileptogennych, pozwala na ich zróżnicowanie ze ścieżkami propagacji zmian, a także na odkrycie występowania istotnych rokowniczo, niemych w innych badaniach, wtórnych ognisk epileptogennych $[16,34]$. ECoG posiada jednak także ograniczenia. Jest procedurą inwazyjną, w 35\% przypadków rejestruje napady o uogólnionym, a nie ogniskowym początku, w 49\% nieprecyzyjnie wskazuje na lokalizacje poza obszarem objętym badaniem oraz rejestruje zmiany o charakterze napadowym o etiologii innej niż dysplastyczna. Problemy te wynikają prawdopodobnie z odległości ogniska od elektrod i głębokości ich umiejscowienia [10]. Pomiędzy $11,7 \%$ a 50\% pacjentów z FCD poddanych leczeniu neurochirurgicznemu wymagało zastosowani tej metody diagnostycznej przed operacją $[4,7,10]$.

Magnetoencefalografia (MEG) jest techniką rejestracji czynności elektrycznej z wykorzystaniem analizy pola magnetycznego wytwarzanego przez mózg. Istniejące doniesienia wskazują na możliwość wykorzystania tego badania celem nieinwazyjnego określania lokalizacji ognisk epileptogennych oraz pomocniczo w rozpoznaniu FCD pomimo braku charakterystycznych zmian w MR [32, 38, 39]. W jednym z badań porównano możliwość lokalizowania ognisk epileptogennych w MEG oraz ECoG. U 8/11 (73\%) pacjentów wynik MEG był zgodny z ECoG. W tym samym badaniu wykazano, że czułość MEG jest porównywalna do tej uzyskiwanej przez MR - 65\% [32]. Yuki Ueda ze współpracownikami podjęli próbę określenia elementów zapisu pozwalających na różnicowanie FCD z innymi jednostkami z aktywnością napadową. Na podstawie dokonanej analizy wykazali, że krótki okres trwania iglic oraz ich strome nachylenie wskazują na FCD [37]. Niestety, nachylenie iglic zmniejsza się wraz z głębokością lokalizacji ogniska, co sprawia, że MEG ma większą czułość dla zmian umiejscowionych w korze nowej niż dla zmian położonych w głębszych strukturach [38]. Co równie istotne, w jednym $\mathrm{z}$ badań, 10/28 pacjentów z rozpoznanym FCD nie wykazało charakterystycznego nagromadzenia iglic w badaniu MEG. 70\% tych pacjentów w momencie przeprowadzenia badania nie ukończyło 5 roku życia. Wydaje się więc, że przydatność tego badania w populacji pediatrycznej może być szczególnie ograniczona [38].

\section{LECZENIE PADACZKI WSRÓD PACJENTÓW Z FCD}

W przypadku wystąpienia objawowej postaci FCD możliwości terapeutyczne zarówno pośród populacji pediatrycznej, jak i dorosłej, w dalszym ciągu pozostają ograniczone. Metodą o największej skuteczności, ale i posiadającą istotne restrykcje, pozostaje leczenie neurochirurgiczne. Skuteczność farmakoterapii jest niesatysfakcjonująca. Brak jest wiarygodnych badań naukowych skupiających się na ocenie klasycznej farmakoterapii w FCD. W oparciu o historie choroby pacjentów poddanych w późniejszym czasie leczeniu operacyjnemu, jej skuteczność szacowana jest na 25-33\% [19]. W piśmiennictwie pojawiają się głównie odniesienia dotyczące monoterapii karbamazepiną i okskarbazepiną, co prawdopodobnie wiąże się z ich rutynowym stosowaniem jako leczenia pierwszego rzutu w przypadku napadów ogniskowych, niezależnie od ich etiologii.

Obecnie pewne nadzieje wiąże się z leczeniem opartym na modyfikacji mechanizmów synaptycznych, a w szczególności zmianach w układzie GABA-ergicznym. Na podstawie serii badań in vitro przeprowadzonych na pobranych od pacjentów z FCD próbkach tkanek, w których zwiększono pobudliwość tkanki nerwowej poprzez zastosowanie 4-aminopirydyny (4-ap) i porównania otrzymanych wyników z wynikami analogicznie przeprowadzonych badań na próbkach pacjentów $\mathrm{z}$ padaczką centralno-skroniową (MTLE), stwierdzono istotne zmiany w funkcjonowaniu receptorów GABA w FCD, powodujące ich paradoksalne działanie. Opisano nieprawidłową, nadmierną aktywność receptorów GABA A oraz obniżoną aktywność receptorów GABA $B$. Zmianom tym przypisuje się epileptogenezę - podanie substancji modulujących działanie receptora GABA A wiązało się ze wzrostem aktywności napadowej $\mathrm{w}$ odpowiedzi na stymulacje w przypadku agonistów, a spadkiem po podaniu antagonistów. Efekt działania fenobarbitalu był zależny od dawki. W niskim stężeniu powodował on wydłużenie aktywności napadowej, w wysokim efekt odwrotny. Z kolei podanie agonisty receptorów GABA B - baklofenu, wywoływało spadek aktywności napadowej, pomimo jej indukowania z użyciem 4-ap. Zastosowanie antagonisty tego receptora przyniosło efekt odwrotny. Autorzy pracy opisali również istotne zaburzenia w homeostazie zależnego od receptorów GABA zewnątrzkomórkowego stężenia potasu. Zaobserwowano jego znaczny wzrost w tej samej lokalizacji, z której inicjowana była aktywność napadowa [25]. Opracowane dane nie pozwalają jednak na określenie czy zmiany te są przyczyną, czy wtórnym do zaburzeń charakterystycznych dla dysplazji korowej mechanizmem kompensacyjnym. W obrębie receptorów GABA A w FCD opisano podjednostki występujące w czasie wczesnej embriogenezy. Z powodu tych zmian klasyczne leki oddziałujące na receptor GABA A mogą nie być skuteczne, jednak dotychczasowe doniesienia są sprzeczne. W jednym z badań na modelu zwierzęcym wykazano szkodliwość tych substancji [19]. W innym, również na modelu zwierzęcym, zaobserwowano zdolność wigabatryny do hamowania mTOR w korze nowej i hipokampie, co może uzasadniać jej skuteczność w TSC oraz wskazywać na możliwość jej zastosowania w FCD [40]. Dotychczasowe próby zastosowania $\mathrm{w}$ populacji pediatrycznej leczenia opartego na modyfikacji układu GABA okazały się nieskuteczne - z uwagi na wystąpienie efektów ubocznych badanie kliniczne nad zastosowaniem bumetanidu i barbituranów u niemowląt z napadami padaczkowymi zostało zamknięte na etapie I/II. Wydaje się, że lepszym i bezpieczniejszym celem terapii niż presynaptyczne stężenie GABA, czy receptory GABA A, są metabotropowe receptory GABA B [19, 25].

Jednym z najbardziej obiecujących celów dla potencjalnej farmakoterapii FCD jest odpowiedzialny za szereg procesów regulujących rozwój tkanki nerwowej szlak mTOR. Wpływa on m.in. na proliferacje komórek, syntezę białek, wzrost, oraz cytoarchitekturę neuronów. Jego patologiczna hiperaktywność jest związana z licznymi jednostkami 
chorobowymi, m.in. z padaczką. Aktualnie leki oparte na inhibicji mTOR znajdują zastosowanie m.in. w stwardnieniu guzowatym, a wyniki badań są obiecujące. Dlatego, $\mathrm{z}$ uwagi na opisane podobieństwa między TSC i FCD oraz doniesienia potwierdzające udział mTOR w patogenezie FCD, trwają intensywne badania nad możliwością zastosowania takiego leczenia w ogniskowej dysplazji korowej [22]. Obecnie otwarte są dwa badania kliniczne nad skutecznością i bezpieczeństwem zastosowania everolimusu w FCD. Pierwsze z nich jest badaniem pilotażowym i obejmuje grupę pacjentów z FCD oraz TSC, drugie obejmuje jedynie pacjentów z typem II FCD [41,42]

Dieta ketogenna (DK) znajduje coraz szersze zastosowanie $\mathrm{w}$ populacji pacjentów pediatrycznych z padaczką lekooporną o różnej etiologii. W jednym $\mathrm{z}$ badań zastosowanie DK u 47 pacjentów pediatrycznych z padaczką lekooporną i FCD pozwoliło na osiągnięcie ustąpienia napadów po 3 miesiącach leczenia u $44,7 \%$ oraz redukcję o $>50 \%$ napadów u dalszych $17 \%$. W momencie zakończenia diety po 2 latach, bez napadów pozostawało 16 pacjentów, tj. 34\%. W czasie kolejnych miesięcy po zaprzestaniu diety, liczba ta zmalała do $9(19,1 \%)$. U większości pacjentów, u których dieta okazała się nieskuteczna bądź źle tolerowana, przeprowadzono leczenie neurochirurgiczne-jego wynik pozostawał w zakresie podawanym piśmiennictwo (klasę Engel I osiągnęło 59,1\%) [43]. Aktualnie pod nazwą EDIBLE zarejestrowane jest badanie kliniczne nad wpływem DK na FCD w populacji pediatrycznej - trwa rekrutacja pacjentów [44].

Pośród innych potencjalnych celów dla farmakoterapii, nad którymi prowadzone są aktualnie badania, znajdują się między innymi: receptory NMDA i patologiczna koekspresja genów NR1 i NR2, zaburzenia w funkcjonowaniu potencjałozależnych kanałów sodowych oraz hipoteza dotycząca aktywacji procesów zapalnych w obrębie tkanki nerwowej mózgu jako przyczyny zmian zaistniałych w FCD [22].

Pomimo opisanych powyżej możliwości farmakoterapii, resekcja ogniska epileptogennego, o ile jest możliwa, nadal pozostaje najskuteczniejszą dostępną metodą leczenia. Według dotychczasowych doniesień od 50 do $80 \%$ pacjentów poddanych tej metodzie rok po operacji pozostaje wolnymi od napadów [4, 6, 7, 10, 14, 19]. Wieloletnia obserwacja wykazała, że pośród tych pacjentów, w 80\% stan ten utrzymuje się w kolejnych latach. Leczenie przeciwpadaczkowe można znacząco zredukować bądź całkowicie odstawić u ok 40\% pacjentów pozostających w długoletniej obserwacji [7]. Klasę IV wg Engela, czyli całkowity brak efektu leczenia odnotowuje się w 6-11\% [7, 14]. Zakres operacji obejmuje, w zależności od przypadku, wycięcie: ogniska, pojedynczego lub kilku zajętych płatów bądź półkuli mózgu. Znaczącym ograniczeniem tej metody leczenia jest potencjalne sąsiadowanie zmian $\mathrm{z}$ istotnymi ośrodkami mózgowymi - szczególnie ośrodka mowy [10].

Najistotniejszym czynnikiem rokowniczym dla leczenia neurochirurgicznego jest całkowite usunięcie ogniska epileptogennego. Poza niekompletną resekcją, jako czynniki ryzyka niepowodzenia wymienia się: pozaskroniową lokalizację ogniska, niemożność określenia lokalizacji źródła w EEG, ogniskowe napady przechodzące w obustron- ne toniczno-kloniczne, konieczność użycia elektrod wewnątrzczaszkowych, brak ognisk w MR, istniejący deficyt intelektualny [4, 45]. Fauser i współautorzy na podstawie analizy wieloletniej (trwającej od 2 do 12lat) obserwacji 211 pacjentów z FCD poddanych leczeniu neurochirurgicznemu udowodnili, że istotnie statystyczne dla rokowania są 4 czynniki: wielkość obszaru zajętego przez zmianę (lepiej rokują przypadki ograniczone do jednego płata), kompletność resekcji, długość okresu napadowego (dłuższy czas trwania padaczki pogarsza rokowanie) oraz wiek w momencie operacji (lepsze rokowania dla pacjentów poniżej 18r życia)[7]. Ostatni spośród wymienionych czynników budzi wątpliwość z uwagi na sprzeczne doniesienia innych autorów tzn. zarówno niewykazujące statystycznie istotnych różnic dla wieku operacji, jak i wskazujące późniejszy wiek operacji jako korzystniejszy rokowniczo [4, 45]. Nie wykazano istotnych statystycznie różnic dla wyniku leczenia w różnych grupach histologicznych zmian [7, 18]. Różnie określany jest okres czasu, jaki musi upłynąć od operacji do adekwatnej oceny skuteczności leczenia i dalszego rokowania - od 3 do 12 miesięcy [7, 18, 45]. Szacuje się, że kompletna resekcja jest niemożliwa u ok 30-35\% pacjentów [10, 12]. W tych przypadkach, w porównaniu do całkowitej resekcji, szanse na uzyskanie całkowitej redukcji napadów maleją z 77\% do 20\% [10]. Reoperacja konieczna jest u 9-54\% pacjentów $[7,10,12]$. W jej wyniku sukces terapeutyczny w postaci całkowitego ustąpienia napadów osiągnie 26-60\% pacjentów, a u dalszych $20 \%$ wystąpi istotna poprawa kliniczna [7, 13]. Czynnikiem o największym znaczeniu rokowniczym dla reoperacji jest spójność wyniku MR oraz ECoG przeprowadzonych przed drugim (bądź kolejnym) zabiegiem [13]. Powikłania pooperacyjne dotyczą 13-22\% pacjentów, a znaczna ich większość ma charakter przejściowy. Tylko u 2\% wystąpiły trwałe (powyżej 3 miesięcy) następstwa operacji - deficyty neurologiczne oraz wodogłowie [10].

\section{WNIOSKI}

Pomimo obszerności piśmiennictwa opisującego problematykę FCD, jednostka ta pozostaje szczególnym wyzwaniem na wielu polach. Mimo ciągłego rozwoju i wzrastającej dostępności nowoczesnych badań, u znacznej części pacjentów z FCD nie udaje się postawić rozpoznania, chociaż powodem diagnostyki są objawy charakterystyczne dla tej jednostki tj. głównie padaczka. Dalszy rozwój metod diagnostycznych wydaje się być warunkiem prowadzącym do poprawy w zakresie prawidłowej kwalifikacji pacjentów do zabiegu operacyjnego, a także uzyskiwania lepszych wyników w leczeniu padaczki związanej z występowaniem FCD. Konieczne jest także opracowanie nowych oraz udoskonalenie już istniejących, nieoperacyjnych metod leczenia FCD.

\section{PIŚMIENNICTWO}

[1] Hauptman J.S.. Mathern G.W.: Surgical treatment of epilepsy associated with crtical dyslasia: 2012 update. Epilepsia 2012; 53: 98-104.

[2] Taylor D.C., Falconer M.A., Bruton C.J., et al.: Focal dysplasia of the cerebral cortex in epilepsy. J Neurol Neurosurg Psychiatry 1971; 34: 369-387.

[3] Leach J.L., Greiner H.M., Miles L. et al.: Imaging Spectrum of Cortical Dysplasia in Children. Semin. Roentgenol. 2014; 49: 99-111. 
[4] Műhlebner A., Grőppel G., Dressler A., et al.: Epilepsy surgery in children and adolescents with malformations of cortical development - Outcome and impact of the new ILAE classification on focal cortical dysplasia. Epilepsy Res. 2014; 108: 1652-1661.

[5] Blümcke I., Thom M., Aronica E., et al.: The clinicopathologic spectrum of focal cortical dysplasias: A consensus classification proposed by an ad hoc Task Force. Epilepsia 2011; 52: 158-174.

[6] Tassi L., Garbelli R., Colombo N.: Type I focal cortical dysplasia: surgical outcome is related to histopathology. Epileptic Disord 2010; 3: 181-191.

[7] Fauser S., Essang C., Altenmuller D.M.: Long-term seizure outcome in 211 patiens with focal cortical dysplasia. Epilepsia 2015; 56: 66-76.

[8] Sisodiya S.M., Fauser S., Cross J.H., et al.: Focal cortical dysplasia type II: biological features and clinical perspectives. Lancet Neurol 2009; 8: 830-843.

[9] Blűmcke I., Sarnat H.B.: Somatic mutations rather than viral infection classify focal cortical dysplasia type II as mTORopathy. Curr Opin Neurol 2016; 29: 388-396.

[10] Lerner J.T., Salomon N., Hauptman J.S.; Assessment and surgical outcomes for mild type I and severe type II cortical dysplasia: A critical review and the UCLA experience. Epilepsia 2009; 50: 1310-1335.

[11] Bartolini L., Whitehead M., Ho C.: Temporal lobe epilepsy and focal cortical dysplasia in children: A tip to find the abnormality. Epilepsia 2017; 58: 113-122.

[12] Krsek P., Maton B., Jayakar P.: Incomplete resection of focal cortical dysplasia is the main predictor of poor postsurgical outcome. Neurology 2009; 72: 217-223.

[13] Sacino M.F., Ho C.Y., Whitehead M.T.: Repeat surgery for focal cortical dysplasias in children. J Neurosurg Pediatr 2017; 19: 174-181.

[14] Kim Y.H., Kang H.C., Kim D.K.: Neuroimaging in identifying focal cortical dysplasia and prognostic factors in pediatric and adolescent epilepsy surgery. Epilepsia 2011; 52: 722-727.

[15] Fauser S., Essang C., Altenmuller D.M.: Is there evidence for clinical differences related the new classification of temporal lobe cortical dysplasia? Epilepsia 2013; 54: 909-917.

[16] Fauser S., Sisodiya S.M., Martinian L., et al.: Multi-focal occurrence of cortical dysplasia in epilepsy patients. Brain 2009; 132: 2079-2090.

[17] Maynard L.M., Leach J.L., Horn P.S., et al.: Epilepsy prevalence and severity predictors in MRI-identified focal cortical dysplasia. Epilepsy Res 2017: 132: 41-49.

[18] Xue H., Cai L., Dong S., et al.: Clinical characteristics and post-surgical outcomes of focal cortical dysplasia subtypes. J Clin Nerosc 2016; 23 . $68-72$

[19] Guerrini R., Duchowny M., Jayakar P.: Diagnostic methods and treatment options for focal cortical dysplasia. Epilepsia 2015; 56: 1669-1686.

[20] Becker A.J., Urbach H., Scheffler B., et al.: Focal cortical dysplasia of Taylor's balloon cell type: mutational analysis of the TSC1 gene indicates a pathogenic relationship to tuberous sclerosis. Ann Neurol 2002; 52: 29-37.

[21] Nakashima M., Saitsu H., Takei N.: Somatic Mutations in the MTOR Gene Cause Focal Cortical Dysplasia Type Ilb. Ann Naurol 2015; 78 : 375-386.

[22] Galanopoulou A.S., Gorter J.A., Cepeda C.: Finding a better drug for epilepsy: The mTOR pathway as an antiepileptogenic target. Epilepsia 2012; 53: 1119-1130.

[23] Chen J., Tsai V., Parker W.E., et al.: Detection of human papillomavirus in human focal cortical dysplasia type IIB. Ann Neurol 2012; 72: 881-892.

[24] Liu S., Lu L., Cheng X., et al.: Viral infection and focal cortical dysplasia. Ann Neurol 2014; 75: 614-616.

[25] Antuono M., Louvel J., Kohling R., et al.: GABA A receptor-dependent synchronization leads to ictogenesis in the human dysplastic cortex. Brain 2004; 127: 1626-1640.

[26] Cepeda C., Andre V.M., Flores-Hernandez J., et al.: Pediatric cortical dysplasia: correlations between neuroimaging, electrophysiology and location of cytomegalic neurons and balloon cells and glutamate/GABA synaptic circuits. Dev Neurosci 2005; 27: 59-76.

[27] Radhakrishnan R., Leach J., Mangano F., et al.: Prospective detection of cortical dysplasia on clinical MRI in pediatric intractable epilepsy. Pediatr Radiol 2016; 10: 1430-1438.

[28] Barkovich A., Kuzniecky R., Bollen A., et al.: Focal transmantle dysplasia: a specific malformation of cortical development. Neurology 1997; 49: 1148-1152.

[29] Halac G., Delil S., Zafer D., et al.: Compatibility of MRI and FDGPET findings with histopathological results in patients with focal cortical dysplasia. Seizure 2017; 45: 80-86.

[30] Mellerio C., Labeyrie M.A., Chassoux F., et al.: 3T MRI improves the detection of transmantle sign in type 2 focal cortical dysplasia. Epilepsia 2014; 55: 117-122

[31] Eltze C.M., Chong W.K., Bhate S., et al.: Taylor-type Focal Cortical Dysplasia in Infants: Some MRI Lesions Almost Disappear with Maturation of Myelination. Epilepsia 2005; 46: 1988-1992.

[32] Bouet R., Mauguiere F., Dalingault S., et al.: The relationship between morphological lesion, magnetic source imaging and intracranial stereoelectroencephalography in focal cortical dysplasia. Neuroimage Clin 2017: 15: 71-79.

[33] Pittau F., Dubeau F., Gotman J.: Contribution of EEG/fMRI to the definition of the epileptic focus. Neurology 2012; 78: 1479-1487.

[34] Thornton R., Vulliemoz S., Rodionov R., et al.: Epileptic networks in focal cortical dysplasia revealed using electroencephalography - functional magnetic resonance imaging. Ann Neurol 2011; 70: 822-837.

[35] Nobili L., Cardinale F., Maliola U.: Taylor's focal cortical dysplasia increases the risk of sleep-related epilepsy. Epilepsia 2009; 50: 2599_ 2604.

[36] Chassoux F., Rodrigo S., Semah F., et al.: FDG-PET improves surgical outcome in negative MRI Taylor-type focal cortical dysplasias. Neurology 2010; 75: 2168-2175.

[37] Krsek P., Kudr M., Jahodova A., et al.: Localizing value of ictal SPECT is comparable to MRI and EEG in children with focal cortical dysplasia. Epilepsia 2013; 54: 351-358.

[38] Ueda Y., Egawa K., Ito T., et al.: The presence of short and sharp MEG spikes implies focal cortical dysplasia. Epilepsy 2015; 114: 141-146.

[39] Ishii R., Canuet L., Ochi A., et al.: Spatially filtered magnetoencephalography to identify. Epilepsy res 2008; 81: 228-232.

[40] Zhang B., McDaniel S.S., Rensing N.R., et al.: Vigabatrin inhibits seizures and mTOR pathway activation in a mouse model of tuberous sclerosis complex. PLoS one 2013; 8.

[41] Devinsky 0., Hopkins M. Weiner H. et al.: A Pilot Study To Evaluate The Effects of Everolimus on Brain mTOR Activity and Cortical Hyperexcitability in TSC and FCD. New York University School of Medicine. Adres: http://clinicaltrials.gov/ct2/show/NCT02451696

[42] Heung Dong K.: A Prospective, Randomized, Double-blind, Placebocontrolled Cross Over Study Investigating the Anti-epileptic Efficacy of Afinitor (Everolimus) in Patients With Refractory Seizures Who Have Focal Cortical Dysplasia Type II (FCD II). Yonsei University. Adres: http:// clinicaltrials.gov/ct2/show/NCT03198949

[43] Jung D.E., Kang H.C., Kim H.D.: Long-Term Outcome of the Ketogenic Diet for Intractable Childhood Epilepsy With Focal Malformation of Cortical Development. Pediatrics 2008; 122: 2008-2012.

[44] Cross H. et al.: A Randomised Controlled Trial to Compare Seizure Remission Outcome Following Resective Surgery With or Without Prior Treatment With Ketogenic Diet in Children With Epilepsy the Result of Focal Cortical Dysplasia Type II. Adres: http://www.edible.org.uk

[45] Mrelashvili A., Witte R.J., Wirrell E., et al.: Seizure Freedom in Children With Pathology-Confirmed Focal Cortical Dysplasia. Pediatr Neurol 2015; 53: 513-518. 
